\title{
POLICE USE OF FORCE: Assessing Necessity and Proportionality
}

\author{
KEVIN CYR ${ }^{*}$
}

\begin{abstract}
This article seeks to clarify the limits imposed on police use of force. It argues that police use of force must be necessary, proportional and lawful. Police officers' safety practice often leads them to act on mere suspicion and contradicts with the probability-based thinking required by law - there must be reasonable grounds to warrant the use of force. Therefore, this article proposes an alternative use of force model adopted by the Edmonton Police. The Edmonton model has been successful in guiding police officers to focus on objectively discernible facts to support their subjective beliefs to meet the threshold on the use of force.
\end{abstract}

\section{TABLE OF CONTENTS}

I. INTRODUCTION . . . . . . . . . . . . . . . . . . . . . 663

II. AUthority to Use ForCE . . . . . . . . . . . . . . . . . . . . . . . . . . . 664

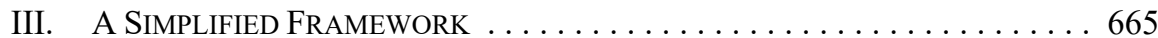

A. NeCESSITY . . . . . . . . . . . . . . . . . . 666

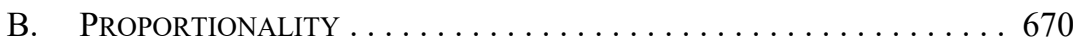

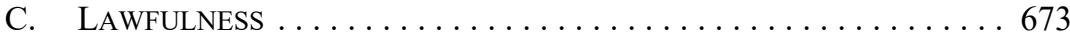

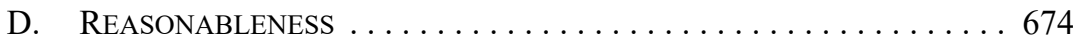

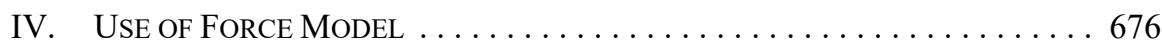

V. CONCLUSION ............................... 679

\section{INTRODUCTION}

The necessity of the occasional use of force by the police in the execution of their duties is self-evident. Indeed, Professor Bittner defined the police as "an institution with the monopoly to employ non-negotiably coercive force in situations where its use is unavoidably necessary." However, the exercise of that monopoly is constrained by public expectations ${ }^{2}$ and legal requirements, ${ }^{3}$ which create avenues of recourse against the police unless the police remain within the bounds of their proper legal authority. Unfortunately, that authority is dimly defined and poorly understood. ${ }^{4}$

This article seeks to clarify the limits placed on the use of force by police. To do so, I argue that police use of force can best be assessed by separating the concepts of reasonable force and necessary force, which are often conflated into a single question of "reasonably necessary force," into distinct questions of proportionality and necessity. In my proposed

BSc, LLM (Osgoode Hall). I have been a police officer with the Royal Canadian Mounted Police (RCMP) for 14 years. The views expressed here are solely my own and do not represent the views of the Government of Canada or the RCMP.

Egon Bittner, The Functions of the Police in Modern Society (Chevy Chase, Md: National Institute of Mental Health, 1970) at 122.

$2 \quad$ Hon Frank Iacobucci, Police Encounters with People In Crisis: An Independent Review Conducted by the Honourable Frank Iacobucci for Chief of Police William Blair, Toronto Police Service (Toronto: Toronto Police Service, July 2014), online: <www.torontopolice.on.ca/publications/files/reports/ police_encounters_with_people_in_crisis_2014.pdf $>$ at 194 ("The use of force by police should always be a last resort. Resolving conflicts through communication rather than force is the goal"). $R v$ Nasogaluak, 2010 SCC 6, [2010] 1 SCR 206 at para 3 [Nasogaluak]. Bittner, supra note 1 at 38 . 
framework, reasonable force is limited to an analysis of whether the force used was proportionate to the threat that the police officer had reasonable grounds to believe they faced. Necessary force, on the other hand, is a much broader question of whether the police intervention that required the use of force was actually necessary, incorporating concepts of de-escalation and officer-created jeopardy. I aim to expand upon the comments of Justice Lebel in Nasogaluak, where he stated, "the allowable degree of force to be used remains constrained by the principles of proportionality, necessity and reasonableness."

In the process of constructing this new framework, I will also discuss some of the practical challenges faced by police officers when they are required to use force. Further, I shall demonstrate that the "use of force wheel"6 currently supported by the Canadian Association of the Chiefs of Police is not representative of the standards and expectations that Canadian police are held to. Instead, I advocate the adoption of an alternative use of force model created by the Edmonton Police Service (EPS) that better incorporates the concepts of necessity and proportionality based on a foundation of lawful presence and assessed through a lens of reasonableness.

Before proceeding, it must be stated that I make a distinction between police brutality and excessive force. I define the former as a malfeasant application of force that is completely severed from lawful police action and motivated by maliciousness, anger, or a misguided attempt at meting out extra-judicial punishment. I define "excessive force," on the other hand, as a use of force that is executed with every intention of being lawful, but that nonetheless exceeds what is acceptable in the circumstances. Police brutality is beyond the scope of this discussion. For the following, all uses of force are assumed to be lawfully intended.

\section{Authority to Use Force}

The principle of legality that the police "may act only to the extent that they are empowered to do so by law" is a fundamental premise of a liberal democracy. ${ }^{8}$ In the present inquiry, this leads to the question, by what legal mechanism are the police empowered to use force in the execution of their duties? The commonly understood answer to this question, by the police ${ }^{9}$ and even experienced legal counsel, ${ }^{10}$ is that section 25 of the Criminal Code provides this authority:

$5 \quad$ Nasogaluak, supra note 3 at para 32

6 An example of this support can be found in various locations, such as in James Drennen, "Use of Force Frameworks" (Presentation delivered at the Canadian Association for Civilian Oversight of Law Enforcement (CACOLE) Conference, 2009), online: <www.cacole.ca/confere-reunion/pastCon/ presentations/index2009-eng.shtml>.

$7 \quad$ R v Mann, 2004 SCC 52, [2004] 3 SCR 59 at para 15.

$8 \quad$ Steve Coughlan, "Charter Protection against Unlawful Police Action: Less Black and White Than It Seems" in Benjamin L Berger \& James Stribopoulos, eds, Unsettled Legacy: Thirty Years of Criminal Justice under the Charter (Markham: LexisNexis, 2012) 239 at 240.

9 On the RCMP website, the Criminal Code, RSC 1985, c C-46, s 25 is referenced under the heading "Legal Authorities for Use of Force." See RCMP, "Legal Authorities for Use of Force," online: <www. rcmp-grc.gc.ca/ccaps-spcca/cew-ai/pol-aut-eng.htm>.

10 Eccles v Bourque, [1975] 2 SCR 739 at 742 [Eccles] ("It is the submission of counsel for the respondents that a person who is by s. 450 authorized to make an arrest is, by s. 25 , authorized by law to commit a trespass with or without force in the accomplishment of that arrest, provided he acts on reasonable and probable grounds"). 
(1) Every one who is required or authorized by law to do anything in the administration or enforcement of the law

(b) as a peace officer or public officer,

is, if he acts on reasonable grounds, justified in doing what he is required or authorized to do and in using as much force as is necessary for that purpose. ${ }^{11}$

However, section 25 does not provide lawful authority to use force. Rather, it serves as a shield from criminal or civil liability, ${ }^{12}$ creating the "peace officer defence" if the use of force was properly justified. Instead, the authority for the police to use force is derived from the ancillary powers doctrine ${ }^{13}$ which requires an assessment of whether the police conduct falls within the general scope of any duty imposed on the police, and whether the conduct involved an unjustifiable use of powers associated with that duty. ${ }^{14}$

Of course, one might ask if there is a practical difference between being authorized to do something, or being justified in having done something? Put another way, does it matter whether it is section 25 or the ancillary powers doctrine that provides the authority to use force? I would assert that, from the perspective of the officer on the street, the distinction is immaterial. Indeed, applications of section 25 and the ancillary powers doctrine both utilize similar verbiage and limit the police to using "reasonably necessary" force. ${ }^{15}$ However, I argue that such a broadly worded standard is difficult for police officers to understand and apply, and conflates the entirely separate concepts of necessity and proportionality. ${ }^{16}$

\section{SIMPLIFIED FRAMEWORK}

To remedy this problem, I propose a framework that separates the concept of "reasonably necessary force" into distinct concepts of necessity and proportionality, built on a foundation of lawful police action, and assessed through a lens of reasonableness. Under my proposed model, reasonable force is limited to an analysis of whether the force used was proportionate to the threat that the police officer had reasonable grounds to believe they faced. Necessary force, on the other hand, is a much broader analysis of the circumstances as a whole and a

11 Criminal Code, supra note 9, s 25.

$12 \quad R v$ Asante-Mensah (2001), 204 DLR (4th) 51 at para 51, aff'd 2003 SCC 38, [2003] 2 SCR 3 [AsanteMensah SCC]. See also Eccles, supra note 10 at 742.

13 Dedman $v$ The Queen, [1985] 2 SCR 2 at 34.

14 Ibid at 32-33; Asante-Mensah SCC, supra note 12 at para 51; see also $R v$ Leeson, 2008 ONCJ 720, 2008 ONCJ 720 (CanLII) at para 15; $R$ v Scott, 2014 ABPC 159, 2014 ABPC 159 (CanLII) at paras 119-21.

15 Asante-Mensah SCC, ibid at para 51 (“At common law, an interference with the arrested person's liberty, including the use of force, must be no more than is "reasonably necessary"'); Sharpe v London Police Services Board, 2010 ONSC 6040, 2010 ONSC 6040 (CanLII) at para 25 ("Sections 25 and 26 of the Criminal Code of Canada justify police using as much force as is reasonably necessary to prevent the plaintiff from interfering in the lawful arrest of his grandson").

16 Iacobucci, supra note 2 at 201 ("The force used must be proportionate, or reasonably necessary, in the circumstances") at 201 . 
question of whether the police intervention that required the use of force was actually necessary.

\section{A. NECESSITY}

Whether or not a use of force was necessary is a logical starting point for our analysis. However, when attempting to assess necessity, we must be careful to ask the proper question. That is, it may be tempting to ask a question such as "was it necessary for the police officer to use his firearm to enable him to take a suspect who was wielding an axe into custody?" But that is the wrong question, and we are merely asking if a firearm is a proportionate response to an axe. Instead, we need to take a much broader view of necessity and ask whether it was necessary for the officer to take the suspect into custody in the first place. Only when the answer is in the affirmative do we move to assessing if the force used to accomplish that goal was proportionate.

This is not a novel approach to the issue. In Asante-Mensah SCC, Justice Binnie stated that " "reasonable force' in the context of the [Trespass to Property Act] may have to have regard not only to what force is necessary to accomplish the arrest, but also to whether a forcible arrest was in all the circumstances a reasonable course of action in the first place." 17 Of course, by pursuing this analysis, we now find ourselves in need of a definition of "necessity" for uses of force.

A definition can be easily adapted from section 186(1)(b) of the Criminal Code, which is the so-called investigative necessity requirement for obtaining an authorization to intercept private communications. This requires that police officers establish "that other investigative procedures have been tried and have failed, other investigative procedures are unlikely to succeed or the urgency of the matter is such that it would be impractical to carry out the investigation of the offence using only other investigative procedures." " The Court has held that "investigative necessity" does not suggest a method of last resort, but rather is a requirement that " $[\mathrm{t}]$ here must be, practically speaking, no other reasonable alternative method of investigation, in the circumstances of the particular criminal inquiry." 19

This definition of necessity is transferrable to police uses of force. Before an officer can use force, she should be satisfied, based on a subjective-objective test meeting the threshold of reasonable grounds to believe, that other intervention tactics have been tried and have failed, are unlikely to succeed, or are impracticable (which, in this context, would mean unsafe) to attempt. Further, uses of force need not be options of last resort, but rather there must be, practically speaking, no other reasonable alternative method of intervention. When we define necessity in this manner, we see that it can be further distilled into an obligation to de-escalate a situation if practicable.

That police attempt to de-escalate situations before using force is either an increasing expectation by the public and the courts, or one that is becoming more clearly defined. For 
example, in 2013, in response to the fatal shooting of Sammy Yatim on a Toronto street car by a member of the Toronto Police Service (TPS), the Ontario Ombudsman launched an investigation into the training of Ontario police officers in de-escalation of situations that may result in the use of force..$^{20}$ In 2014, the Toronto Police Service, likely motivated by the same incident, had the Honourable Frank Iacobucci conduct an independent review of TPS "policies, practices and procedures of, and the services provided by, the TPS with respect to the use of lethal force or potentially lethal force, in particular in connection with encounters with persons who are or may be emotionally disturbed, mentally disturbed or cognitively impaired." 21 That review included findings on de-escalation tactics by Toronto Police members.

This increased focus on de-escalation has resulted in tangible new requirements placed on the police. For example, the Braidwood Inquiry, looking into the 2007 death of Robert Dziekanski at Vancouver International Airport, recommended that the police not deploy a Conducted Energy Weapon ("CEW") unless "de-escalation and/or crisis intervention techniques have not been or will not be effective in eliminating the risk of bodily harm." 22 The province of British Columbia has implemented this as policy guiding police officers using a CEW. ${ }^{23}$ However, one might ask why, if there is an obligation to de-escalate a situation before the use of a CEW, there is not the same obligation for other uses of force? Is there something fundamentally different about the use of a $\mathrm{CEW}$ that imparts an obligation to de-escalate when other uses of force do not bear such a requirement? I would submit that is not a tenable argument.

Justice Iacobucci's findings supported this broader application of the obligation for the police to de-escalate situations if possible, stating:

\begin{abstract}
There is no doubt that many TPS officers employ such communication in their interactions with people with mental health issues, other people in crisis, and other subjects of police response. The Review heard from many people within the TPS that front line officers practice de-escalation on a daily basis, and are familiar with how to de-escalate. While I have no doubt that this is largely true, it is clear that there have been lethal encounters between police and a person in crisis in which de-escalation was an option that was not fully explored. Yet it is at precisely these moments that de-escalation matters most. ${ }^{24}$
\end{abstract}

Police agencies have been responding to these expectations. For example, the Edmonton Police Service (EPS) and researchers from the University of Alberta investigated ways to improve outcomes when dealing with mental health and addiction issues, and delivered training on both verbal and non-verbal communication, de-escalation techniques, empathetic

Ontario Ombudsman, “Annual Report 2013-2014 Update: De-escalation direction to police - Ministry of Community Safety and Correctional Services," online: <www.ombudsman.on.ca/investigations/ SORT-investigations/In-Progress/Ontario-direction-to-police-on-de-escalation/Case-update---AnnualReport-2013-2014-\%281\%29.aspx>.

21 Iacobucci, supra note 2 at 4.

Braidwood Commission on Conducted Energy Weapon Use, Restoring Public Confidence: Restricting the Use of Conducted Energy Weapons in British Columbia (Victoria, BC: Braidwood Commission on Conducted Energy Weapon Use, 2009) at 309.

23 British Columbia, Police Services Division, Ministry of the Attorney General, Provincial Policing Standards, (Victoria: Ministry of the Attorney General, 2015) online: $<$ www2.gov.bc.ca/assets/gov/lawcrime-and-justice/criminal-justice/police/standards/provincial-policing-standards.pdf $>$ at 1.3.1. Iacobucci, supra note 2 at 200. 
understanding, and mental-health knowledge to EPS officers. Among other benefits, they found that over a six month period there was a greater than 40 percent decrease in the use of any kind of force when interacting with mentally ill individuals, although there were other internal police initiatives that may have also helped with that reduction. ${ }^{25}$

A corollary to the requirement to de-escalate situations is the need to avoid "officercreated jeopardy," ${ }^{26}$ that being where an officer takes unnecessary action which then creates a situation that requires force to resolve. As stated in Chartier v. Greaves, "[a] police officer should, where possible, explain why an obvious alternative but less dangerous course of action was not taken." ${ }^{27}$ The classic example of officer-created jeopardy is when a police officer stands in the path of a fleeing stolen vehicle, thereby creating a situation where the officer has to shoot the driver under the fear that the driver is trying to run him over. While it is true that the officer has a duty to apprehend the driver, and it is true that the officer's life is in danger from the fleeing car, the inescapable conclusion is that the officer's actions are a significant contributor to the risk, and, depending on the circumstances, those actions may be in pursuit of an unnecessary purpose. This is akin to the investigative requirement for police to avoid, if possible, creating exigent circumstances that then, due to the manufactured exigency, require a warrantless search. ${ }^{28}$

That said, policing is an endeavour that necessarily involves risk, and every police action that incurs risk does not equate to officer-created jeopardy. There are many situations that are urgent, where de-escalation cannot be attempted, and risk is unavoidable. As explained in Chartier, "[a] police officer is not at liberty to shirk his/her duty. If he/she does, he/she may be charged with "neglect of duty." "'29 Indeed, an officer can find himself in a situation where failure to intervene results in criminal liability. ${ }^{30}$ However, it is risk created by inappropriate police action that unreasonably deviates from established strategy and doctrine that constitutes officer-created jeopardy.

Assessing the optimal method and timing of intervention is a tactical decision based on a number of considerations that go beyond the scope of this analysis. However, the goals of that tactical assessment are readily understood. Sometimes, the officer may wish to take action without trying to de-escalate in an attempt to capture the initiative and prevent the suspect from deciding on and implementing a violent course of action. Other times, it is preferable for the officer to slow the situation down and attempt to de-escalate, thereby giving the suspect an opportunity to calm down, realize the gravity of the situation, and see the merits in ending the situation peacefully.

Unfortunately, which course of action is better in a given situation is impossible to determine with certainty, for it requires a police officer to judge if intercession by force now

Yasmeen Krameddine et al, "Preventing Violent Encounters: De-escalation Training For Police,"(2014) RCMP Gazette 76:1 20 at 21, online: <http://www.rcmp-grc.gc.ca/gazette/vol76no1/index-eng.htm>. Louis Hayes, "Command, tactical, and weapons training model - Critical operational decision-making," ITOANews (Fall 2011) at 13, online: $<$ www.itoa.org/training_model/ITOA_NEWS_the_illinois_model_ series 1 Hayes.pdf>.

[2001] ŌJ No 634 (QL) (Sup Ct J) at para 64 [Chartier].

See generally $R v$ Silveira, [1995] 2 SCR 297.

Chartier, supra note 27 at para 64.

Ian D Scott, "Legal Framework of Use of Force by Police in Ontario" (2008) 53:3 Crim LQ 331 at 333. 
is preferable to possible intercession by force in the future along some unpredictable progression of events. This assessment requires an extrapolation of a subject's current behaviour in an attempt to anticipate their future behaviour. This is an incredibly difficult calculation, particularly in a high stress environment when faced with potential harm and precious little time to make such a decision.

An example can aptly demonstrate the challenges of making these decisions in real time. As a young patrol officer working in a rural community, I was dispatched to a domestic assault complaint. Upon transferring to this community I had been warned by veteran officers about this particular family — the husband was notoriously violent but the wife would always refuse to provide statements. In the days before more robust domestic violence intervention strategies, repeatedly dealing with this family was accepted as an unavoidable issue.

When I arrived at their dilapidated duplex, I found the wife, sporting fresh injuries, standing on the front porch holding their six-month-old baby in her arms. The drunken husband was standing next to the wife, yelling at her. When I stepped out of my police car, he turned his aggression towards me, challenging me to fight him. Seeing how the incident was progressing, I told the wife to go inside. She did, taking the baby with her. I told the husband he was under arrest and I expected a fight to ensue. But his response was not what I had anticipated. He turned and ran into the house after his wife. I followed on his heels.

Even though I was only seconds behind him, by the time I got into the house the situation had changed dramatically. The wife and husband were in the kitchen, engaged in a tug of war over the baby. The husband was saying, "Let me say goodbye to the baby," albeit in a tone that was very aggressive, and the wife was understandably refusing. The situation was clearly at a critical juncture and I was required to make an immediate decision. Should I take the husband at his word that his intentions with the baby were entirely legitimate and his saying goodbye to the baby would facilitate his coming with me cooperatively? Or should I assume that if the intoxicated husband got the baby, he would use the baby as a hostage to regain control of the situation? If I decided the situation would probably progress along the latter course, should I intervene by force immediately, even though the baby would be put in some danger if I did so? Or should I wait to see if it in fact unfolded in that manner and then negotiate with the husband, even though he would then have a tremendous advantage and the risk to the baby would be heightened? The time I had to decide on the necessity of action was the time it took me to cross the width of the kitchen at a full run. ${ }^{31}$

It is when we analyze examples such as this that we see "the police are often required to make split-second decisions in fluid and potentially dangerous situations." ${ }^{32}$ The courts recognize the difficulty this presents, and have repeatedly expressed understanding of the police officer's plight. As stated in Chartier:

31 In that circumstance, I decided that the potential danger if the husband did take the baby hostage exceeded the potential danger of me using force to immediately arrest the husband. I was able to break the husband's grip on the baby, and the fight was on. I managed to deliver a solid punch and then tackle him into the wall. As we fell to the ground I landed on top of him and was able to pin him to the ground. The husband then merely said, "where did my glasses go?" and, just like that, his will to fight had evaporated. 
It is one thing to have the time in a trial over several days to reconstruct and examine the events which took place.... It is another to be a policeman in the middle of an emergency charged with a duty to take action and with precious little time to minutely dissect the significance of the events, or to reflect calmly upon the decisions to be taken. ${ }^{33}$

Further, in the oft-quoted Besse v. Thom:

[I]t is well-recognized that police officers have difficult and unenviable duties to perform in modern society. They should not be criticized unduly for making immediate decisions in the course of duty which, when analyzed with exquisite precision after the event, may not be demonstrated to have been the most appropriate decisions to have made. Generally speaking, police officers are deserving of sympathetic consideration of the problems with which they are confronted in the performance of their arduous duties. ${ }^{34}$

\section{B. Proportionality}

Provided that a particular use of force is established as being necessary, we may now move to assessing whether or not it was proportionate to the situation faced. First, however, we must establish what the is goal of the police officer's use of force. In the most common example, the officer is trying to take someone into custody who does not wish to be taken into custody. That is, the officer is attempting to overcome resistance. Of course, this resistance can exist on a spectrum of severity, from merely refusing to cooperate, to pushing the officer away, assaulting the officer in order to facilitate an escape, assaulting the officer with the goal of injuring the officer, or, in the most extreme case, trying to kill the officer.

Regardless of the severity, the police officer must overwhelm the suspect's will to fight or their ability to fight in order to overcome resistance. ${ }^{35}$ An example best illustrates the difference between these two concepts. Suppose the police wish to arrest someone who rolls into a ball and clasps their hands together in front of them. The police officer can either physically force the still-resisting person's hands behind their back to handcuff them (overcoming their ability to fight), or they can, by a number of different means, convince the person to voluntarily put their hands behind their backs (overcoming their will to fight).

I believe that the expectation of the public is that the police, by brute force and superior skill, are able to (or ought to be able to) compel compliance from a still struggling opponent. That is, the public often assumes that the police are most commonly resolving situations by overwhelming a suspect's ability to fight. What is probably not fully appreciated by those who have never attempted to do so is that it is nearly impossible to handcuff someone who does not want to be handcuffed. That is why social media sites are full of videos of multiple police officers struggling with a single suspect — it really is that difficult to do. ${ }^{36}$

$33 \quad$ Chartier, supra note 27 at para 64.

(1979), 96 DLR (3d) 657 (BC Co Ct) at 667.

Of course, "ability and will to fight" is an excessive term for low-level resistance, just as "ability and will to resist" is an insufficient description of violent attacks on police officers. However, for ease of reference, I will only refer to the ability and will to fight.

36 In my opinion, this is also due to a lack of physical fitness standards and a deficiency of ongoing defensive tactics training in most police agencies. However, that is beyond the scope of this article. 
Overpowering someone to the degree that they can be handcuffed requires physical control on a different order of magnitude than merely being stronger than the suspect. It requires a significant numerical advantage and proper use of control techniques, and even then it is very difficult. This difficulty increases with the amount of force that the person is resisting with. That is, it is one thing to forcefully put a resisting but otherwise non-violent person's hands behind his or her back, it is another thing altogether to end a violent attack by a motivated opponent trying to deliver bodily harm to the police officer.

For a violent attack on a police officer by a goal-oriented opponent, the ability to fight is usually only overwhelmed by an injury so catastrophic that the suspect's body is unable to properly function. However, this is not as easy as it may seem. The human body is incredibly durable and even the most extreme use of force - using a firearm — is not guaranteed to incur instant incapacitation. Many grievously wounded persons have remained combat effective for some time. Consider, for example, the story of LAPD officer Stacy Lim who, while off duty, was carjacked by a group of gang members. Despite being shot point blank in the chest with a .357 magnum round that penetrated her heart, she was able to return fire and kill one of the assailants, causing the rest to flee. ${ }^{37}$ As explained by an FBI publication on handgun effectiveness:

\footnotetext{
$[\mathrm{P}]$ hysiological factors may actually play a relatively minor role in achieving rapid incapacitation. Barring central nervous system hits, there is no physiological reason for an individual to be incapacitated by even a fatal wound, until the blood loss is sufficient to drop blood pressure and/or the brain is deprived of oxygen. The effects of pain, which could contribute greatly to incapacitation, are commonly delayed in the aftermath of serious injury such as a gunshot wound. The body engages in survival patterns, the well known "fight or flight" syndrome. Pain is irrelevant to survival and is commonly suppressed until some time later. In order to be a factor, pain must first be perceived, and second must cause an emotional response. In many individuals, pain is ignored even when perceived, or the response is anger and increased resistance, not surrender. $^{38}$
}

Since incapacitating someone's ability to fight is so difficult, and since very few police uses of force progress to that level, one may question by what mechanism do the police more often achieve success? I would argue that, for the vast majority of incidents, the police achieve success by overwhelming the suspect's will to fight. Simply put, the suspect gives up. The question then becomes, why do suspects give up?

A suspect's will to fight can be overcome by using a number of means. For example, communication skills can be used to gain voluntary compliance.$^{39}$ Or the officers can remove bystanders before whom the suspect feels a need to "prove himself." Through using force, compliance can be gained by inducing fear or pain, or by demonstrating the futility of resistance and the impending loss of the fight. For example, while working as a patrol officer, I arrested a young man who pulled a machete on me. ${ }^{40}$ I drew my gun. The suspect later told

Lt Col Dave Grossman \& Loren W Christensen, On Combat: The Psychology and Physiology of Deadly Conflict in War and in Peace, 3rd ed (Illinois: Warrior Science Publications, 2008) at 144-45.

Special Agent Urey W Patrick, "Handgun Wounding Factors and Effectiveness" (Paper delivered at the Firearms Training Unit, FBI Academy, Quantico, Virginia, 14 July 1989) [unpublished] at 8.

See Part A above.

For a full narrative of the event, see Kevin Cyr, "The Police Officer's Plight, The Intersection of Policing and the Law" (2015) 52:4 Alta L Rev 889 at 919. 
me that his will to fight was overwhelmed by the certainty of his losing the encounter in the face of superior force and he surrendered.

Some police intervention options target both the ability to fight and the will to fight. For example, oleoresin capsicum spray (pepper spray) impairs a person's ability to fight by temporarily blinding them. It also impedes their will to fight by moving their thought process off of their goal of fighting the police and instead making them concentrate on eliminating the pain and breathing difficulty caused by the spray.

With this construct, we see that the police officer's goal is to distribute force that overwhelms the suspect's ability or will to fight. If the force is not overwhelming, then the situation will continue and potentially escalate. Note that overwhelming force is limited to what is required to overcome the suspect's ability or will to fight. Anything beyond that will be excessive. With this goal of exerting overwhelming (but not excessive) force established, we can now move to an assessment of what would constitute a proportionate means of achieving that goal.

It is enticing to suggest that the police ought to use only the minimum amount of force necessary for the purpose at hand. For example, a police officer could be expected to use force that matches that used by the suspect, with the goal of eventually overcoming the will or ability to fight. However, doing so is an exceptionally poor idea; standing toe-to-toe and slugging it out until someone falls down is a sure recipe for disaster. Alternatively, an officer could be expected to ascertain the absolute minimum amount of force required in a given situation by following a stepped progression of escalating force until the suspect is successfully subdued. But that is also ill-advised. As soon as the officer demonstrates a willingness to use force to resolve a situation, but fails to overcome the suspect's resistance, the suspect is afforded a window of opportunity to escalate their level of resistance. The officer will also have demonstrated an inability to control the situation, possibly fuelling the suspect's will to fight.

The courts have repeatedly recognized that it is neither practical nor possible for police officers engaged in dynamic situations to "measure the force used with exactitude." ${ }^{41}$ Further, the courts have endorsed the police eschewing a strategy where they attempt to only use the least amount of force which might successfully achieve their objective, recognizing that to do so would result in "unnecessary danger to themselves and others." 42 As with decisions regarding the necessity of police action, police decisions on the proportionality of force are "not assessed through the "lens of hindsight.", 43

Indeed, perhaps counter-intuitively, by the officer using effective overwhelming force, she will be able to gain control quickly and prevent the situation from escalating. In the end, this will ultimately require less force, which ought to translate into a safer resolution of the

$41 \quad R v$ Bottrell (1981), 60 CCC (2d) 211 (BCCA) at 218 ("In determining whether the amount of force used by the officer was necessary the jury must have regard to the circumstances as they existed at the time the force was used. They should have been directed that the appellant could not be expected to measure the force used with exactitude"). See also $R v$ Cornell, 2010 SCC 31, [2010] 2 SCR 142 at para 24 [Cornell].

$42 \quad$ Levesque v Zanibbi, 1992 CarswellOnt 2832 (Sup Ct J (Gen Div)) at para 17.

43 Crampton $v$ Walton, 2005 ABCA 81, 250 DLR (4th) 292 at para 45 [citations omitted]. 
incident. The degree of allowable force will also depend significantly on the threat faced and there are many factors which come into play, including (but not limited to) the police officer's size and strength compared to that of the suspect, relative fitness levels, and whether the suspect is under the influence of drugs. Ultimately, however, the calculation can be distilled to two considerations. The first is determining the difficulty of defeating an adversary's ability or will to fight. The second is assessing the severity of the repercussions if it is not done effectively in the first instance.

\section{LAWFULNESS}

Even uses of force that are necessary and proportionate are not necessarily lawful. An underlying requirement is that the police action that led to the use of force is itself lawful. This requirement is clearly described in section 25 , which states, "[e]very one who is required or authorized by law to do anything." 44 A police officer may use force that is entirely proportionate and necessary to effect an arrest, but if the arrest itself is unlawful then section 25 will be of no assistance.

Such was the problem encountered by RCMP Constable Doucette when he attended a noise complaint at a suspected drug dealing residence late one night. The residents of the house left through the back door when they saw police approaching. Constable Doucette intercepted and detained them, ostensibly for a drug investigation, facing the vociferous objections of one of the suspects who Constable Doucette then forcibly restrained and placed in his police car. ${ }^{45}$ The suspect complained and Constable Doucette was charged with assault and forcible confinement. Although Constable Doucette had ample reason to have his curiosity aroused, he did not meet the required threshold of belief to detain the suspects. ${ }^{46}$ In the absence of lawful authority to conduct the detention, Constable Doucette could not avail himself to the protection of section 25 of the Criminal Code and was convicted. ${ }^{47}$

Perhaps the origin of this issue can be found in the difficulty in understanding and applying police powers. The "scattered collection of statutory and common law rules" makes up police powers has been described as a "complex labyrinth" "bewildering complexity." Adding to this difficulty is the infrequency with which police officers actually use their lawful authorities in a way that is subject to court oversight. Only a small percentage of a police officer's time is spent actually conducting criminal

$44 \quad$ Criminal Code, supra note 9, s 25(1).

$45 \quad R$ v Doucette, 2012 PESC 26, 328 Nfld \& PEIR 1 at para 7.

Ibid at para 40 .

Ibid at para 45 .

James Stribopoulos, "Has the Charter Been for Crime Control? Reflecting on 25 Years of Constitutional Criminal Procedure in Canada" in Margaret E Beare, ed, Honouring Social Justice: Honouring Dianne Martin (Toronto: University of Toronto Press, 2008) 351 at 358.

49 Michal Fairburn, "Twenty-Five Years in Search of a Reasonable Approach" in Jamie Cameron \& James Stribopoulos, eds, The Charter and Criminal Justice: Twenty-Five Years Later (Markham: LexisNexis, 2008) 55 at 55 (discussing search provisions).

50 Don Stuart, Charter Justice in Canadian Criminal Law, 3rd ed (Scarborough: Carswell, 2001) at 260 (discussing the provisions of section 495(2) regarding the limitations of police arrest powers). See also James Stribopoulos, “Unchecked Power: The Constitutional Regulation of Arrest Reconsidered” (2003) 48:2 McGill LJ 225 at 239-40. 
investigations. ${ }^{51}$ Further, only a small set of those cases will result in charges, and only a smaller subset of those charges will proceed to trial where the police action is challenged. Thus, if a police officer's knowledge of their authorities is inaccurate then there are few chances of correction through court oversight.

The danger that an officer will misapply the law is particularly acute when it comes to the intersection of their functions as law enforcers and their larger role in general order maintenance. In the most difficult order maintenance issues, especially when dealing with uncooperative people, the officer may attempt to use her criminal investigative authorities to accomplish her order maintenance goals. This pragmatic use of legal rules in low-visibility encounters when other methods of resolution have failed is a well-established component of police patrol behaviour. ${ }^{52}$ Although there is often overlap between law enforcement and order maintenance that would legitimately allow for such a usage, that is not always the case, and the shoehorning of a criminal investigation solution into an order maintenance problem can result in an unlawful application of police authority. When that application of authority requires a use of force, problems are sure to result.

These problems come into focus when one realizes that, while section 25 of the Criminal Code affords protection to police officers when mistakes are made, that protection only applies to good faith mistakes of fact. ${ }^{53}$ Section 25 will not afford protection to officers if mistakes of law are made, even if they are made in good faith. ${ }^{54}$ That is, a police officer can be honestly mistaken about the circumstances, but not how the law applies to those circumstances. When the law is misapplied, section 25 will not provide protection, regardless of how good the officer's intentions were.

\section{REASONABLENESS}

Although I have suggested that the "reasonably necessary" standard is better described as separate inquiries of proportionality and necessity, I have not discarded the concept of reasonableness as a required part of the equation. On the contrary, in my view reasonableness is the lens through which proportionality and necessity are assessed. That is, section $25(1)$ requires the officer to act "on reasonable grounds," which I take to mean that the officer must believe, on reasonable grounds, that the police intervention is both necessary in the circumstances and proportionate to the threat faced. As with an officer's grounds for arrest, ${ }^{55}$ this belief must be based on both subjective and objective grounds.

51 Curt T Griffiths \& Simon N Verdun-Jones, Canadian Criminal Justice, 2nd ed (Toronto: Harcourt Brace, 1994) at 71 ("crime control activities generally occupy less than $25 \%$ of police officers' time and, for most officers, this figure is considerably lower"). See also Samuel Walker, The Police in America: An Introduction (New York: McGraw-Hill, 1983) at 58.

$52 \quad$ James Stribopoulos, "Packer's Blind Spot: Low Visibility Encounters and the Limits of Due Process versus Crime Control" in François Tanguay-Renaud \& James Stribopoulos, eds, Rethinking Criminal Law Theory: New Canadian Perspectives in the Philosophy of Domestic, Transnational, and International Criminal Law (Oxford: Hart, 2012) 193 at 202.

Supra note 9, s 25(2).

Hudson v Brantford Police Services Board (2001), 204 DLR (4th) 645 at para 24.

$R v$ Storrey, [1990] 1 SCR 241 at 250-51. 
The reasonable grounds standard, being "something more than mere suspicion, but less than the standard applicable in civil matters of proof on the balance of probabilities" an insurmountable obstacle which prevents officers from being able to respond quickly and effectively to a given situation. Further, as described above, police officers are given considerable latitude in their response to dynamic situations. However, achieving the objectively reasonable standard can nonetheless be problematic for police officers. I argue that this is because use of force is a concept that is inextricably linked to officer safety, which introduces cognitive biases due to the threat of interpersonal violence.

The majority of officer safety practices, such as standing in a certain position when conducting a traffic stop, are passive in nature. These types of protective actions are not motivated by any known threat or even probable threat, but rather are predicated on the viewing of all events according to what threat they might pose. ${ }^{57}$ Indeed, such safety practices are only effective when they are applied as a matter of ritual in the absence of outward signs of risk. This requires an application of a possibility-based mindset, and the use of such security measures is not automatically inappropriate. ${ }^{58}$

In circumstances requiring assertive uses of force, officer safety concerns remain at play, but there is an added dimension of legal authority. That is, as the officer progresses from defensive, passive actions such as using a spotlight to illuminate the interior of a car, to offensive, assertive actions such as grabbing hold of someone, the officer must be sure to also transition from the possibility-based thinking which motivates safety practices to the probability-based thinking that the law requires for using force. ${ }^{59}$

Complicating this transition is that threats to safety from interpersonal violence (as is the case in uses of force) motivate a completely different psychological response compared to threats from other sources. ${ }^{60}$ Consider, for instance, that in the last decade a comparable number of police officers in the United States have been killed by vehicle crashes as by gunshots (414 versus 539). ${ }^{61}$ However, far more police officers wear body armour ${ }^{62}$ than wear seatbelts. ${ }^{63}$ Police officers who wear body armour do so because it is "critical for

57 Kevin M Gilmartin, Emotional Survival for Law Enforcement, A Guide for Officers and Their Families, (Tucson: E-S Press, 2002) at 35.

58 Cornell, supra note 41 at para 24 ("It is often said of security measures that, if something happens, the measures were inadequate but that if nothing happens, they were excessive. These sorts of after-the-fact assessments are unfair and inappropriate when applied to situations like this where the officers must exercise discretion and judgment in difficult and fluid circumstances").

See Cyr, supra note 40 at 920 .

Grossman \& Christensen, supra note 37 at 3-4.

National Law Enforcement Officers Memorial Fund, "Causes of Law Enforcement Deaths Over the Past Decade (2005-2014)" (15 September 2015) National Law Enforcement Officers Memorial Fund, online: $<$ www.nleomf.org/facts/officer-fatalities-data/causes.html $>$.

62 Heath Grant et al, "Body Armor Use, Care, and Performance in Real World Conditions: Findings from a National Survey" (Paper submitted to the US Department of Justice, Police Executive Research Forum, 1 November 2012) [unpublished] at 42.

63 US Department of Transportation, Characteristics of Law Enforcement Officers' Fatalities in Motor Vehicle Crashes (Washington, DC: National Highway Traffic Safety Administration, 2011) at 2. (approximately 50 percent of US police officers killed in vehicle crashes were wearing seatbelts). In my experience meeting and working with hundreds of police officers over the course of 14 years, I can only think of two patrol officers who did not wear body armour, and both can be described as "old timers" with less than prudent officer safety practices. On the other hand, I have observed a shockingly high percentage of patrol officers, probably around 40 percent or so, who do not wear their seatbelts. 
safety" ${ }^{\prime 64}$ which necessarily means for protection against being shot. In other words, the action of wearing body armour is motivated by the risk of interpersonal violence. Yet the risk of interpersonal violence is also what motivates officers to not wear their seatbelts - the belief is that if they do so they could be ambushed and unable to get out of their seatbelt in time to respond to the threat. ${ }^{65}$ Even in the face of compelling evidence that wearing a seat

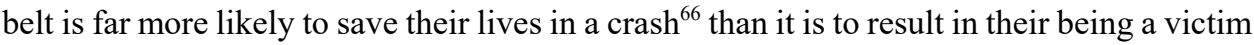
of interpersonal violence, the interpersonal violence motivation wins out.

\section{USE OF FORCE MODEL}

Considering the difficulties that the police face in making use of force decisions, and the dynamic circumstances in which those decisions have to be made, a use of force model is necessary to teach officers how to quickly make acceptable use of force decisions. The most widely utilized model is the National Use of Force Framework (see Figure 1) endorsed by the Canadian Association of Chiefs of Police, ${ }^{67}$ though some other agencies have their own version of it. ${ }^{6}$

This graphical representation demonstrates what would, in most circumstances, be considered an acceptable police action when faced with a given suspect behaviour. For example, for someone who is non-cooperative, meaning they are not exerting force directed at the officer, but are also not cooperating (perhaps by going limp), so-called "soft physical control" techniques, such as grabbing the person, would generally be acceptable. For assaultive behaviour, where the subject is directing force towards the officer, more extreme measures of force are appropriate, such as using police batons ("intermediate weapons") or striking the subject ("hard physical control"). These standards are not prescriptive, and circumstances can require a deviation from them, but they provide a helpful starting point.

Despite the widespread adoption of such "use-of-force wheels," their value is predominately limited to training police officers on the proportionality of use of force decisions, and they lack clarity on broader concerns. Indeed, Justice Iacobucci argued that these wheels are deficient in their emphasis on "de-escalation and communication as part of the use-of-force analysis." ${ }^{69}$ Further, although the model's innermost circle is labeled "officer presence, perception and tactical consideration" (see Figure 1), the model fails to link these concepts to the lawfulness and the necessity of police intervention that gives rise to a use of force.

Gupra note 62 at vi-viii

Kevin Wehr, Geoff Alpert \& Jeffrey Rojek, “'The Fear of the Ninja Assassin:' Understanding the Role of Agency Culture in Injurious and Fatal On-Duty Vehicle Collisions" (2012) 46:2 J California L Enforcement 25 at $29-30$.

Peter Cummings, James D Wells \& Federick P Rivara, "Estimating seat belt effectiveness using matched-pair cohort methods" (2003) 35 Accident Analysis \& Prevention 143 at 143 (estimating that seatbelts result in approximately 40 percent less risk of dying in a vehicle crash). 


\section{FigURE 1:}

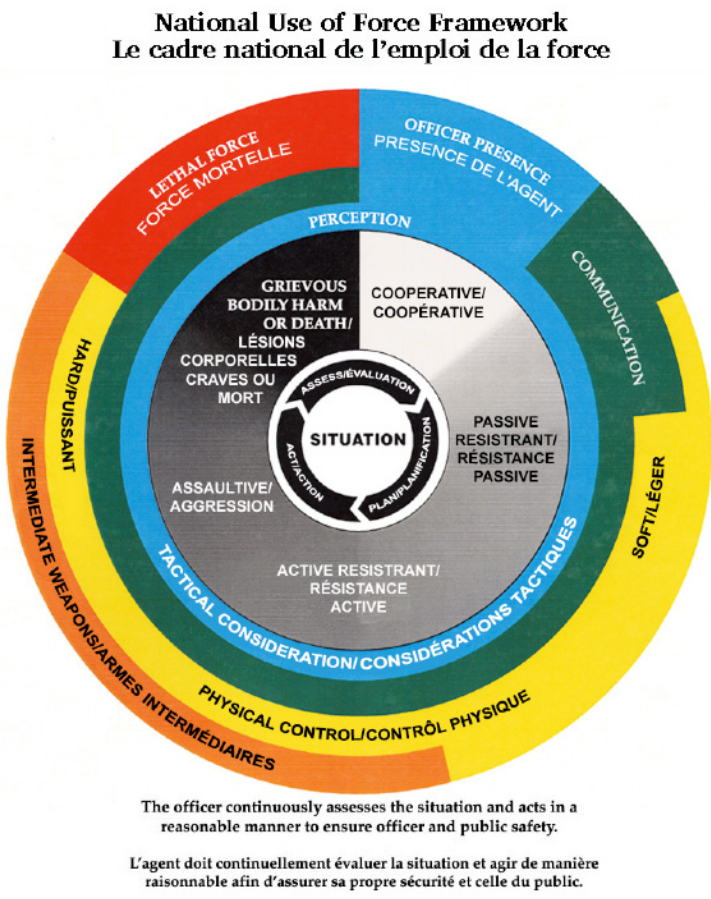

Having realized that the current Use of Force Framework endorsed by the Canadian Association of Chiefs of Police may not be representative of the actual requirements the police must adhere to, we find ourselves in need of an alternative model. In 2009, the Edmonton Police Service implemented one, when they introduced the Reasonable Officer Response model as their use of force frameworks (see Figure 2).$^{70}$ This model is particularly instructive as it places communication skills and tactical considerations (the measures of necessity), as well as lawful presence, as foundational requirements of police intervention. Only once that foundation is established does the level of threat faced then determine proportionate uses of force.

70 Edmonton Police Service, "2010 Edmonton Police Service Control Tactics Year-End Report” (14 February 2011), online: <www.edmontonpolicecommission.com/wp-content/uploads/2014/01/2011_ Control_Tactics_Year_End_Report.pdf $>$. 
FIGURE 2: ${ }^{71}$

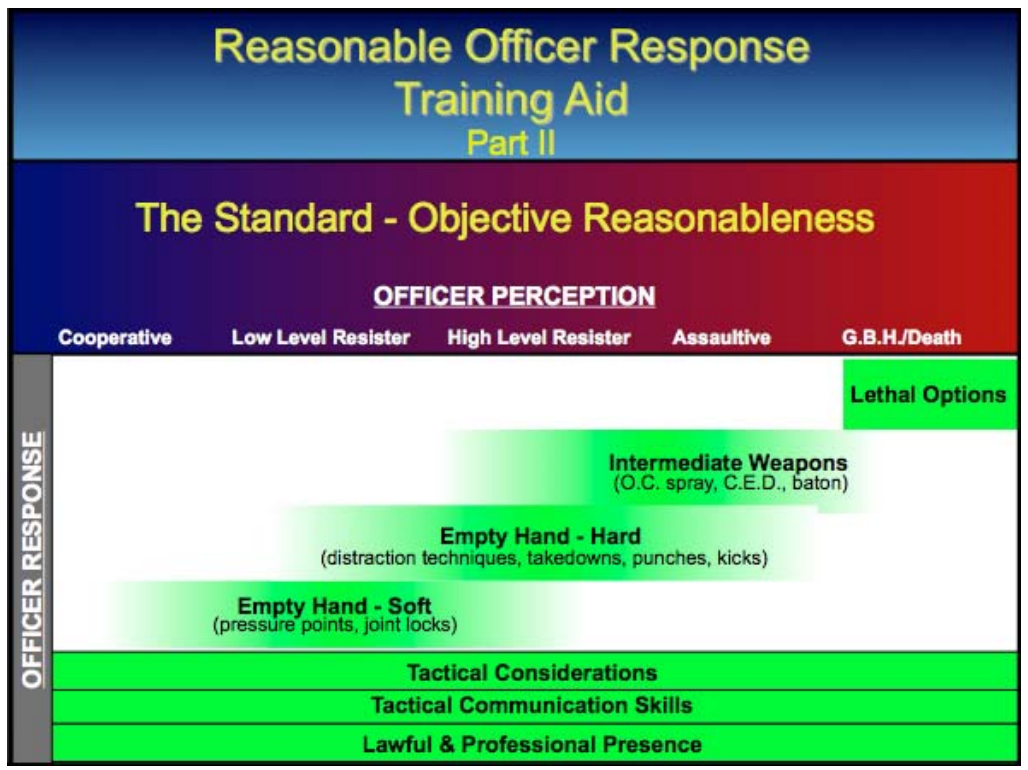

Further, the Reasonable Officer Response model establishes the standard for making use of force decisions as one of "objective reasonableness." This standard prompts officers to ask themselves, "How sure am I that I have to use force, and that the force I intend to use is proportionate?" Such a question naturally guides officers away from uses of force based on pure suspicion and vague possibilities. Instead, it guides the officer to focus on objectively discernible facts to support their subjective beliefs. The CACP model, however, is silent on the standard to which the officer's decisions are held.

This alternative model seems to be effective. In their 2013 report to the Edmonton Police Commission on control tactics statistics, the Edmonton Police Service reported a 40 percent reduction in control tactics occurrences between 2009 and 2013, which they attributed to "the professional awareness of Edmonton Police Service members in relation to the use of force along with thorough reporting and supervisory oversight.,"72

71 Norm Lipinski, "Professionalism in Policing Reasonable Officer Response (ROR)" (Presentation delivered at the Canadian Association for Civilian Oversight of Law Enforcement (CACOLE) Conference, 2009), online: <www.cacole.ca/confere-reunion/pastCon/presentations/index2009-eng. shtml>.

72 Edmonton Police Service, "Edmonton Police Service Control Tactics Statistics 2013 January - June Report" (23 July 2013), online: <www.edmontonpolicecommission.com/wp-content/uploads/2014/01/ EPS_Control_Tactics_Statistics.pdf $>$ at 4. 


\section{CONCLUSION}

The use of force by police officers in a liberal democracy is not a simple matter, either in its theoretical construction or in its actual application. Instead of relying on poorly defined and easily misunderstood standards, I have presented a simple three-part test to assess uses of force. First of all, was the officer engaged in a lawful execution of their duty when they encountered circumstances that required the use of force? Secondly, was the police action that required the use of force necessary? And thirdly, was the police use of force proportionate to the threat faced?

Of course, necessity and proportionality are to be assessed based on a threshold of reasonable grounds, which is an achievable threshold if it is applied with a proper understanding that the police officer's goal is to overwhelm the will and / or ability to fight of the subject being arrested, and that there is precious little time to assess the nuances of the situation. This construct is best supported by the Reasonable Officer Response use of force model, which is superior to the National Use of Force Framework currently in use in Canada. 